\title{
Mapping the scientific output of the Costal Studies Program (PEC) of the Museu Paraense Emílio Goeldi, Belém, Pará, Brazil, as a contribution to coastal ecosystem services \\ Mapeamento da produção científica do Programa de Estudos Costeiros (PEC) do Museu Paraense Emílio Goeldi, Belém, Pará, Brasil, visando serviços de ecossistemas marinhos e costeiros
}

\author{
Heloísa Vargas Borges", "l, Amílcar Carvalho Mendes", Artur Gustavo Oliveira de Miranda", Ana Yoshi Harada" \\ 'Universidade Federal Fluminense. Niterói, Rio de Janeiro, Brasil \\ "Museu Paraense Emílio Goeldi/MCTIC. Belém, Pará, Brasil
}

\begin{abstract}
The Amazon coastal zone comprises an area of $9,000 \mathrm{~km}^{2}$, located between the Oiapoque River in Amapá and São Marco Bay, Maranhão, Brazil. Several environments characterize the area, such as beaches, tidal plains, salty and freshwater marshes, estuaries, mangroves, lowland rainforest, tropical forests, lakes, lagoons, islands, rivers, deltas, dunes. This essay using scientific articles published from 1997 to 2015 by Museu Paraense Emílio Goeldi (MPEG) researchers tries to map the scientific output of the Coastal Studies Program (PEC) that completes 20 years of existence in 2017. The map produced from this bibliographical survey offers data on zoology, botany, geology, anthropology, archeology, ecological and multidisciplinary studies as a contribution to Marine and Coastal Ecosystems Services (MCES).
\end{abstract}

Keywords: Amazon coastal zone. Museu Paraense Emílio Goeldi. Geoinformation.

Resumo: A zona costeira amazônica compreende uma área de 9.000 km², localizada entre o rio Oiapoque, Amapá, e a baía de São Marco, Maranhão, Brasil. Vários ambientes estão presentes nesta área, tais como praias, planícies de maré, pântanos salgados e doces, estuários, manguezais, florestas de várzea, florestas tropicais, lagos, lagoas, ilhas, rios, deltas e dunas. O presente ensaio utiliza artigos científicos publicados entre 1997 e 2015 por pesquisadores do Museu Paraense Emílio Goeldi (MPEG) e tenta mapear a produção científica do Programa de Estudos Costeiros (PEC), que completa 20 anos de existência em 2017. O mapa produzido com o levantamento bibliográfico, visando localizar serviços de ecossistemas marinhos e costeiros, inclui trabalhos nas áreas de zoologia, botânica, geologia, antropologia, arqueologia, ecologia e estudos multidisciplinares.

Palavras-chave: Zona costeira amazônica. Museu Paraense Emílio Goeldi. Geoinformação.

BORGES, H. V., A. C. MENDES, A. G. O. MIRANDA \& A. Y. HARADA, 2017. Mapping the scientific output of the Costal Studies Program (PEC) of the Museu Paraense Emílio Goeldi, Belém, Pará, Brazil, as a contribution to coastal ecosystem services. Boletim do Museu Paraense Emílio Goeldi. Ciências Naturais 11(2): 183-190.

Autora para correspondência: Heloisa Vargas Borges. Universidade Federal Fluminense. Instituto de Geociências. Avenida General Milton Tavares de Souza, s/n - Gragoatá. Niterói, RJ, Brasil. CEP 24210-346 (vargas.heloisa@gmail.com).

Recebido em 18/09/2016

Aprovado em 16/04/2017

Responsabilidade editorial: Fernando da Silva Carvalho Filho

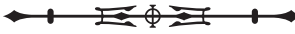




\section{INTRODUCTION}

Brazil occupies $47 \%$ of the area of South American and has a coastline of approximately $8,500 \mathrm{~km}$, of which the Amazon coastal zone occupies 35\%. This coastal belt lies between the Oiapoque River in Amapá $\left(5^{\circ} \mathrm{N}, 51^{\circ} \mathrm{W}\right)$ and the São Marcos Bay in Maranhão ( $\left.2^{\circ} \mathrm{S}, 44^{\circ} \mathrm{W}\right)$, where in are found different environments such as beaches, tidal plains, salty and fresh water marshes, estuaries, mangroves, lowland rainforest, tropical forests, lakes, lagoons, islands, rivers, deltas, dunes.

In the ecosystem context mangrove forests dominate the Amazon coastal zone, spreading along the coast of three states, Amapá, Pará, and Maranhão, and account for $70 \%$ of
Brazil's mangroves, covering an area of about $9,000 \mathrm{~km}^{2}$ (Menezes \& Mehlig, 2009). When associated with the mangroves of French Guiana, Suriname, and Guyana, this ecosystem constitutes one of the largest, if not the largest, mangrove belt on the planet (Figure 1).

In Brazil, the main scientific centers producers are the universities that concentrate mostly on research and development investments and, consequently, have the largest number of researchers (Guimarães, 2004) and postgraduate programs. This prevalence of universities in scientific production is also recognized in developed countries like the United States of America, France, Germany (Meadows, 1999).

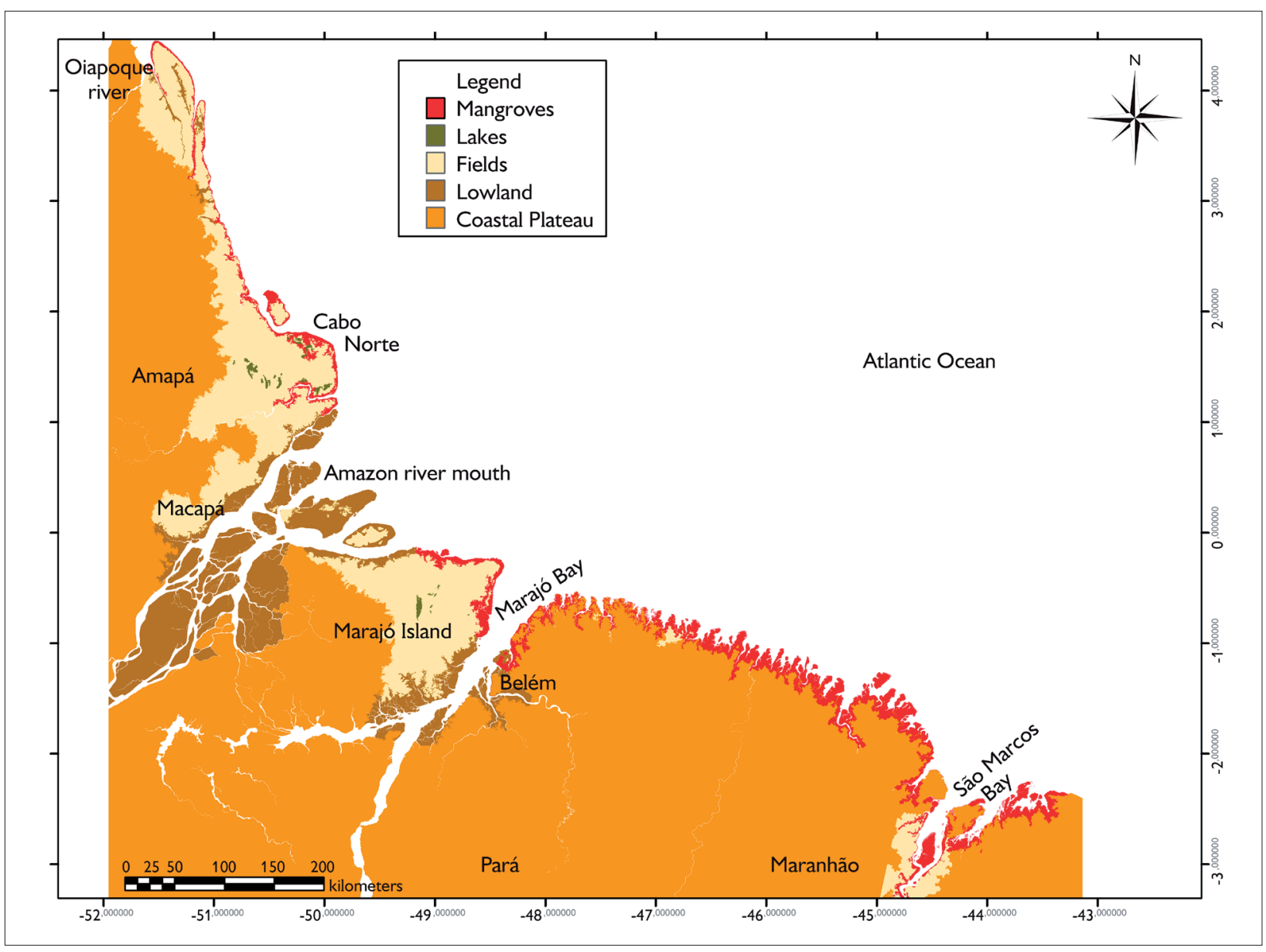

Figure 1. The Brazilian Amazon coastal zone is located between the Oiapoque River in Amapá ( $5^{\circ} \mathrm{N}, 51^{\circ} \mathrm{W}$ ) and São Marcos Bay in Maranhão $\left(2^{\circ} \mathrm{S}, 44^{\circ} \mathrm{W}\right)$.

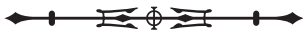


The assessment of scientific output has gained the attention of different research areas, such as the sociology of science and scientometrics, besides being of interest to national agencies and international organizations concerned with science and technology (Souza et al., 2012).

The use of quantitative indicators in Brazil, for the analysis of science, technology, and innovation, by different levels of government are used to define guidelines, allocation of resources, and investments, among other activities (Mugnaini et al., 2004). Berti et al. (2010) consider these indicators of scientific activity essential to the development of public policies in this sector.

This article is a follow-up a bibliographic survey of indexed articles published by members of the Coastal Studies Program (PEC) from the Museu Paraense Emílio Goeldi (MPEG) in Belém, Pará, Brazil.

The Coastal Studies Program (PEC) was created in 1997 and has focused on the Amazon coastal zone ecosystems. The proposal of the program is to undertake multidisciplinary and interdisciplinary research, dedicated to the study of environmental and social aspects in order to generate subsidies for territorial and natural resource management, as well as support for the formulation of public policies.

The Coastal Studies Program is structured along six thematic axes: 1) dynamics of the coastal physical environment, 2) biological inventory, 3) biological dynamics and evolutionary history, 4) socio-cultural and environmental dynamics, 5) environmental management and public policy, and 6) training and building human resources capacity, and communication and outreach.

At this time, the program has 43 members of whom 12 are researches linked to graduate programs (masters and doctorate). In addition to the researchers, the program includes scholars from outside the MPEG (visiting researchers, undergraduate and graduate fellows, and others).

The main goal of this paper is to identify the major areas of scientific output of the Coastal Studies Program, relating these to the staging areas where they were produced and the geographical distribution of effort, data collection, and knowledge generation in the Amazon coastal zone. The survey is not a bibliometric study, but aims at quantifying and locating geographically the scientific output from 1997 to 2015. The MPEG in 2016 celebrated 150 years of foundation, and we wanted to know how much the institutional research program PEC, dedicated to coastal environments, contributed to the knowledge of the Amazon coastal zone.

Mapping all the scientific work done by the MPEG is an important contribution, but we did not include historical publications, data from museum collections, or from other Amazonian institutions. This paper is part of a larger project to include the entire Amazon coastal zone that will enable us to construct an information platform for public consultation by the general and scientific public on conservation projects and environmental policy. In that way we will be able to identify the gaps in our knowledge and to propose new research projects.

\section{MATERIALS AND METHODS}

Scientific articles selected from the MPEG digital archive (MPEG, s. d.), from the Boletim do Museu Paraense Emílio Goeldi, and other scientific journals were organized in an excel spreadsheet to facilitate organization. These were separated by scientific discipline and their geographical locations, from the coordinates for latitude and longitude it was then possible construct a map to serve as a source of information for Marine and Coastal Ecosystems Services (MCES) (Harada \& Senna, 2016).

The bibliographic search utilized the Lattes Platform (CNPq, s. d.) maintained by the Brazilian National Research and Development Council (Conselho Nacional de Desenvolvimento Científico e Tecnológico - CNPq) to document the curricula of Brazilian researchers since the mid-1980s.

Only complete articles published in indexed journals were selected because this publication type constitutes an institutional performance indicator by the Ministry of Science, Technology, Innovation and Communications. The master excel spreadsheet included 154 scientific articles, 
among other types of publication such as books, scientific reports, dissertations, and pamphlets. A second spreadsheet was then generated using filters for coordination, scientific area, and scientific sub-area. To this second spreadsheet, toponyms, such as city, beach, municipality, state, and their geographical coordinates were added.

\section{CARTOGRAPHIC REPRESENTATION OF SCIENTIFIC OUTPUT}

The resulting, verified map accurately shows the correct distribution of information (Figure 2). Four different icons, CZO (Coordenação de Zoologia), CBO (Coordenação de Botânica), CCTE (Coordenação de Coordenação de Ciências da Terra e Ecologia) and CCH (Coordenação de Ciências Humanas), represent zoology, botany, ecology, and social sciences, respectively, to identify these four areas.

\section{RESULTS AND DISCUSSION}

Over the study period (1998-2015), researchers from the Coastal Studies Program published 154 scientific papers. The historical series showed that the average annual scientific output for articles is 8.5 per year, with higher production peaks in 2001,2005, 2013, and 2014, with a period of lower output in 2002 and 2003 (Figure 3). These peaks in scientific production were related to large grants that made possible field work, data collection, and the publication of articles. The most difficult part of any field research in the Amazon is the lack of infrastructure and logistics. In the Amazon coastal zone high tides, strong currents, adverse climate, and long distances with few roads are all difficulties to be overcome.

The scientific papers are distributed in all major areas: 70 articles in botany (CBO), 40 in zoology (CZO), 28 in ecology (CCTE), 16 in social sciences (CCH) (Table 1; Figure 4). The concentration of papers in zoology and botany is a reflection of the larger number of researchers who work in these areas. The production of zoological and botanical papers is due to the graduate programs (masters and doctorate degrees) in these areas, although only four and five researchers, respectively, were the responsible graduate advisors. Consequently, this has increased the number of dissertations and theses produced by graduate students and their resulting published papers.

According to MPEG annual reports, the scientific output of the Coastal Studies Program has grown considerably in recent years, starting in 2000. The increase in scientific production is related to two main factors: firstly, to grants for long-term research projects in coastal and oceanic environments, as well as mangrove mapping and vegetation association (grants from Petrobras and the German government), and secondly to the creation of graduate degree-granting courses that increased the number of graduate students, especially with the course in tropical botany in 2005 jointly by the MPEG and the Federal Rural University of Amazon (Polette, 2006).

Another factor for increasing scientific output was implementation of the Institutional Training Program (Programa de Capacitação Institucional - PCI) that supported to the MPEG through funding of stipend fellows with masters and doctoral degrees, in fulfilling the institutional mission and strategic planning objectives in strategic areas of activity: research, scientific collections, scientific innovation, public science communication, and information technology.

Two indicators of institutional performance involve the measurement of scientific output: a) Publication Index (PI) and b) General Publication Index (GPI). The first corresponds to the number of scientific articles produced in indexed journals of level B1 and A. The second corresponds to the sum of articles published in periodicals with an International Standard Serial Number (ISSN) and indexed in General Index Publication (GPI) or another database, articles published in national or international scientific journal of divulgation, complete articles published in national or international congress and chapter of books in the year. In the last three years (2014-2016), the contribution of the Costal Studies Program to the MPEG IP score was less than 9\%, with a significant reduction in 2015 (Figure 5). With respect to PCI, the Costal Studies Program's contribution is slightly higher, around 10\%, with a slight reduction in 2015 (8\%). 


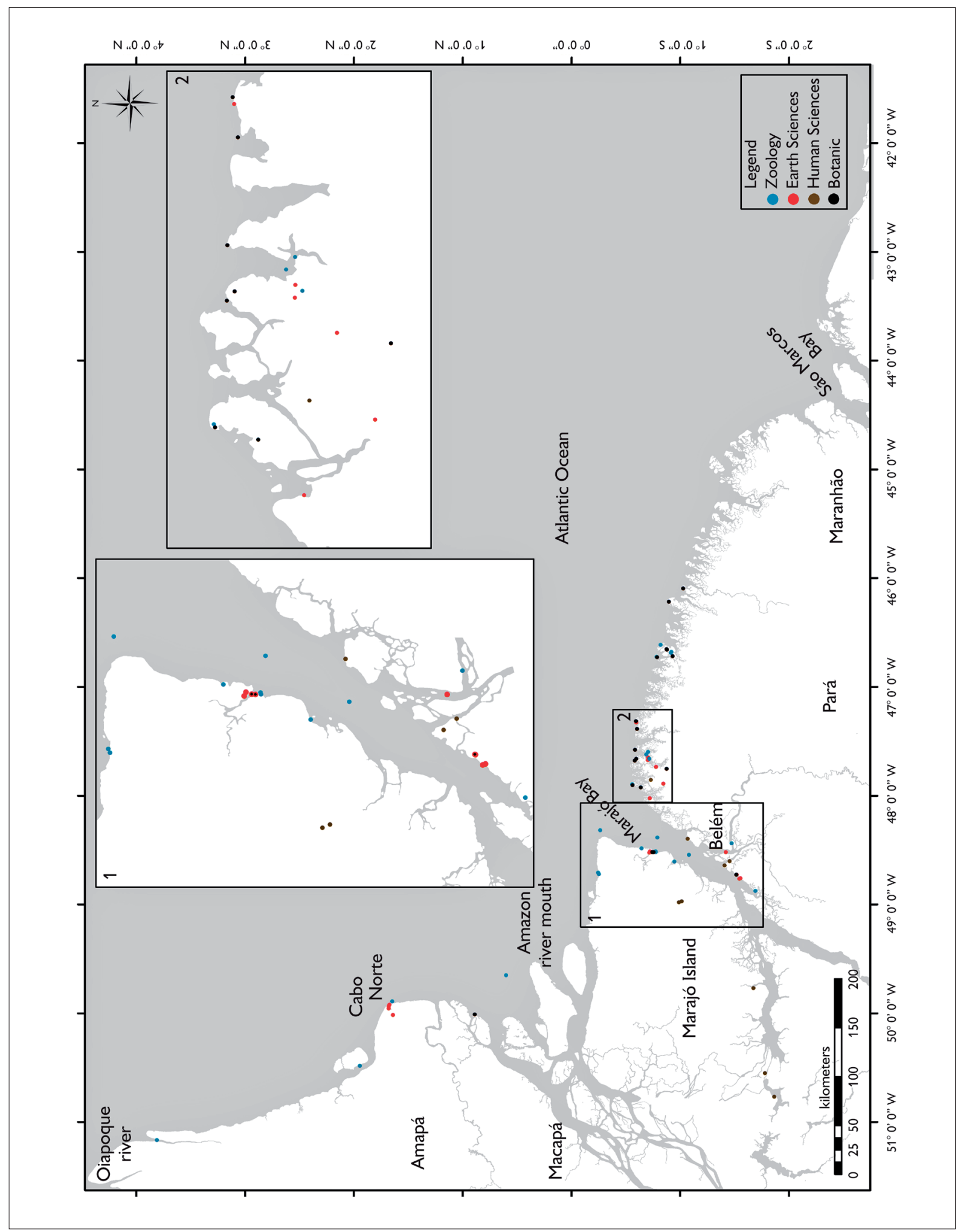

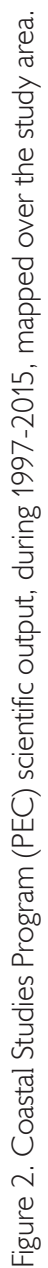

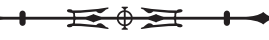




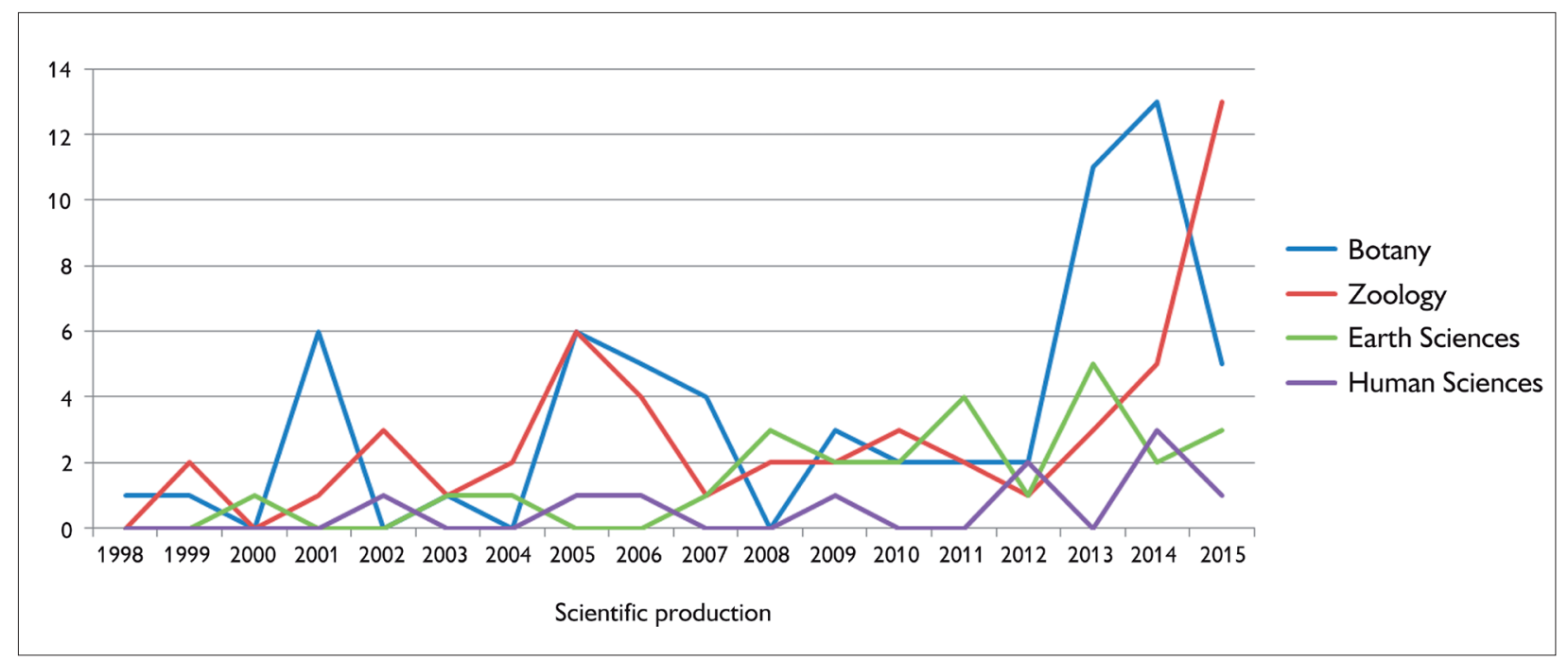

Figure 3. The average annual scientific output in articles was 8.5 per year, with peaks in 2001, 2005, 2013, and 2014, with lower production in 2002 and 2003.

Table 1. Sample organization of data obtained for publications with geographical locations.

\begin{tabular}{c|c|c|c|c}
\hline Coordination & Area & Sub-area & Location & Geographical coordinates \\
\hline CBO & Life Sciences & Botany & Marudá, Municipality of Marapanim & $\begin{array}{c}0^{\circ} 40^{\prime} 24^{\prime \prime} \mathrm{N}, 47^{\circ} 38^{\prime} 00^{\prime \prime} \mathrm{W} \text { to } \\
00^{\circ} 37^{\prime} 06^{\prime \prime} \mathrm{N}, 47^{\circ} 34^{\prime} 42^{\prime \prime} \mathrm{W}\end{array}$ \\
\hline CBO & Life Sciences & Botany & Zone of Salgado, Algodoal Island & $0^{\circ} 35^{\prime} 17,33^{\prime \prime} \mathrm{S}, 47^{\circ} 34^{\prime} 27,25^{\prime \prime} \mathrm{W}$ \\
\hline CBO & Life Sciences & Botany & Canela Island, Municipality of Bragança & $0^{\circ} 47^{\prime} 06^{\prime \prime} \mathrm{S}, 46^{\circ} 43^{\prime} 41^{\prime \prime} \mathrm{W}$ \\
\hline
\end{tabular}

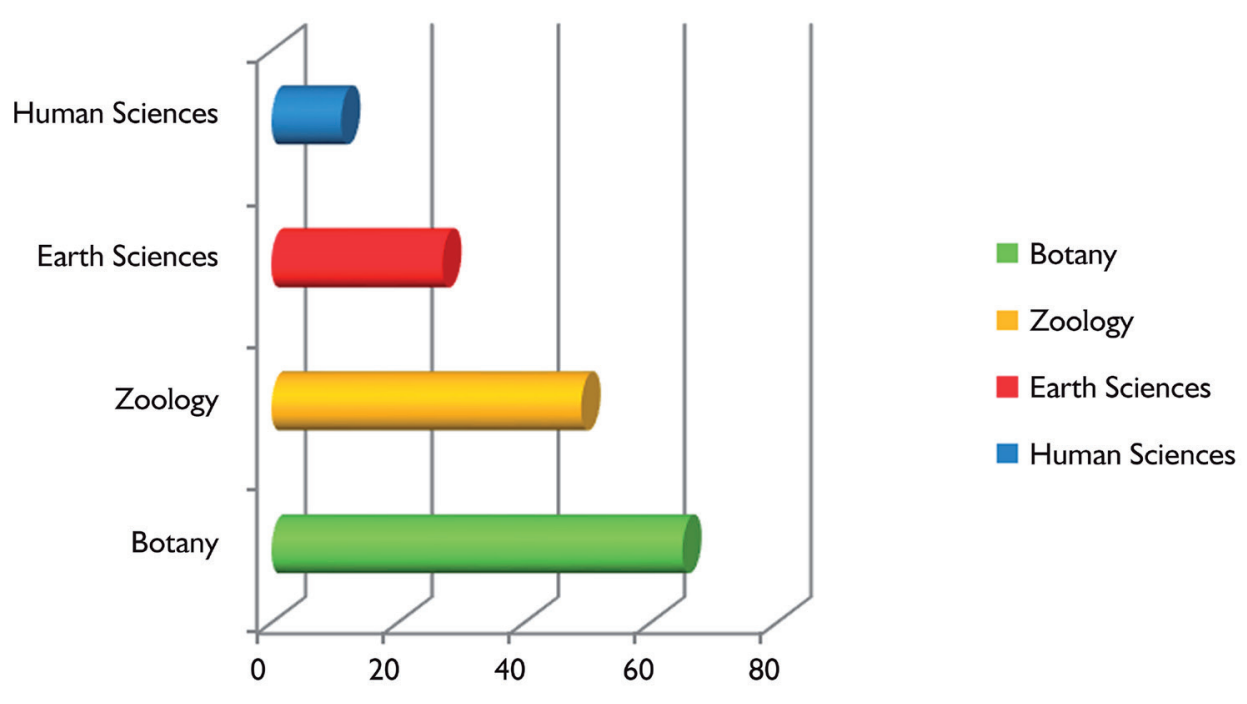

Figure 4. Coastal Studies Program (PEC) scientific production from 1997 to 2015, by major areas of knowledge.

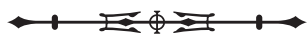




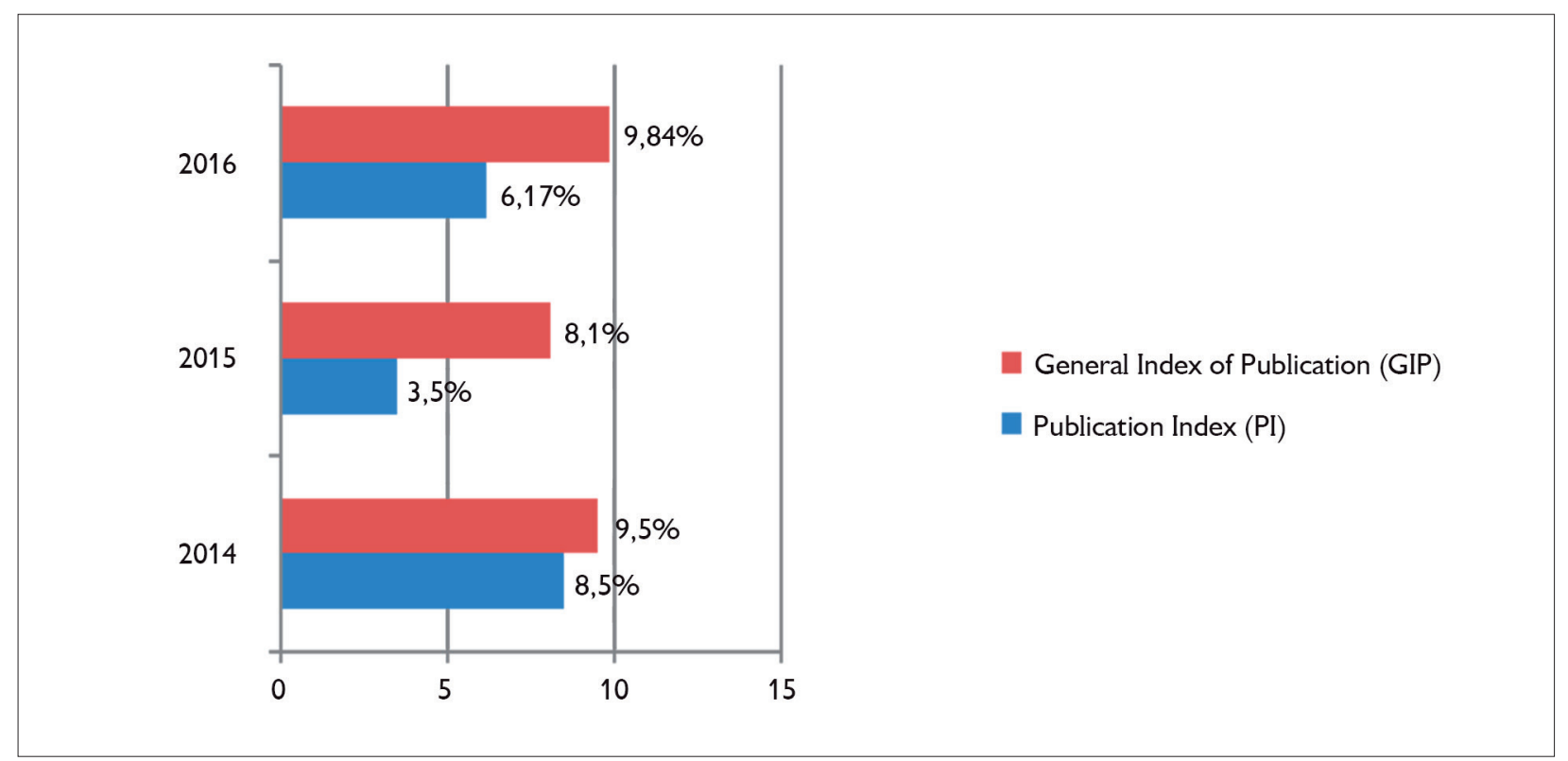

Figure 5. Contribution of the Costal Studies Program to MPEG institutional performance from 2014 to 2016, which involve the measurement of scientific output: Publication Index (PI) and General Publication Index (GPI).

The observed reduction in the indicators in 2015 can be explained by the retirement of several researchers associated with the Program in 2014. On the other hand, the increase in 2016 is due to the incorporation of visiting researchers with masters or doctoral degrees, as well as the production of masters and doctoral students linked to the Coastal Studies Program.

\section{CONCLUSIONS}

The areas of botany and zoology have provided most of the scientific output of the Costal Studies Program, reflecting the infrastructure and funding for fieldwork in these traditional areas of the MPEG. The concentration of graduate studies in this geographical location is due to the relative ease of access.

The large dispersion in the themes of scientific output reinforces the multidisciplinary nature of the Costal Studies Program. Most contributions of the program are in the life sciences, especially botany, a measure of the importance of biotic resources to the local population.

In absolute terms, the contributions of the Coastal Studies Program to the MPEG institutional scientific production indicators may be considered low in metric terms, but these contributions are nonetheless important and significant, given the available infrastructure for field and laboratory studies, especially with regard to limited human resources.

The Coastal Studies Program is a relatively new research program considering that the MPEG is 150 years old. Historically the scientific research of the museum has been directed to the study the socio-biodiversity of the Amazon, mostly concentrating resources on continental forest ecosystems, in terms of research projects and institutional investments.

In probable future scenarios, the scientific output of the Costal Studies Program can be expected to decline in coming years. In the last two years (2015-2016), 12 researchers have retired, which means fewer projects are under active development and fewer graduate students are being advised. This scenario is further aggravated because the Brazilian federal government does not confirm the possibility of recomposing the research team during the next three years. 


\section{ACKNOWLEDGMENTS}

This work was made possible by funding travel and living expenses in Belém for the first author through a grant from MPEG. The authors would like to acknowledge the valuable assistance and technical support from MPEG Documentation and Information Coordination and it's entire staff. Many MPEG scientists helped us locate missing references or provided copies of their papers. We also thank the anonymous reviewers for their swift and insightful comments.

\section{REFERENCES}

BERTI, L. C., D. L. OLIVEIRA, D. O. SOUZA \& S. T. WOFCHUK, 2010. Produção científica e formação de recursos humanos na área de bioquímica em instituições federais no Rio Grande do Sul: fomento estadual. Química Nova 33(3): 765-771. DOI: http:// dx.doi.org/10.1590/S0100-40422010000300051.

CONSELHO NACIONAL DE DESENVOLVIMENTO CIENTÍFICO ETECNOLÓGICO (CNPQ), [s. d.]. Plataforma Lattes. Disponible in: <http://lattes.cnpq.br/>. Accessed on: 2016.

GUIMARÃES, J. A., 2004. A pesquisa médica e biomédica no Brasil: comparações com o desempenho científico brasileiro e mundial. Ciência \& Saúde Coletiva 9(2): 303-327. DOI: http://dx.doi. org/10.1590/S1413-81232004000200009.
HARADA, A. Y. \& C. S. F. SENNA, 2016. Contribuição do MPEG para o conhecimento científico e a formação de recursos humanos na Amazônia costeira. Anais do Congresso Ibero-Americano de Gestão Integrada de Áreas Litorais 2: 665-666.

MEADOWS, A. J., 1999. A comunicação científica. Briquet de Lemos Livros, Brasília.

MENEZES, M. P. M. \& U. MEHLIG, 2009. Manguezais: as florestas da Amazônia costeira. Ciência Hoje 44(264): 34-39.

MUGNAINI, R., P. M. JANNUZZI \& L. QUONIAN, 2004. Indicadores bibliométricos da produção científica brasileira: uma análise a partir da base Pascal. Ciência da Informação 33(2): 123-131. DOI: http://dx.doi.org/10.1590/S010019652004000200013

MUSEU PARAENSE EMÍLIO GOELDI (MPEG), [s. d.]. Repositório. Disponible in: <http://repositorio.museu-goeldi. $\mathrm{br} />$. Accessed on: 2016.

POLETTE, M., 2006. Avaliação do processo de gestão do Programa de Estudos Costeiros - PEC da Amazônia. Relatório Interno. MPEG, Belém.

SOUZA, A. R., D. M. SANTIN \& S. Z. SCHARDONG, 2012. Mapeamento temático da produção científica do Programa de Pós-Graduação em Neurociências da UFRGS: 1998-2010. Anais do Seminário Nacional de Bibliotecas Públicas Universitárias 3: 246-258. 